\title{
Occurrence of Chaetogaster limnaei K. von Baer, 1927 (Oligochaeta, Naididae) associated with Gastropoda mollusks in horticultural channels in Southeastern Brazil
}

\author{
Martins, $R T$.* and Alves, $R G$. \\ Programa de Pós-graduação em Ciências Biológicas, Comportamento e Biologia Animal, \\ Departamento de Zoologia, Instituto de Ciências Biológicas, Universidade Federal de Juiz de Fora, \\ Campus Universitário, CEP 36036-330, Juiz de Fora, MG, Brasil \\ *e-mail: martinsrt@gmail.com
}

Received March 25, 2009 - Accepted May 5, 2009 - Distributed November 30, 2010

\begin{abstract}
The aim of this study was to evaluate the presence of Chaetogaster limnaei K. von Baer, 1927 in four species of mollusks collected in irrigation channels of a horticultural garden in the city of Juiz de Fora, Minas Gerais State, Southeastern Brazil. The collections were made from June 2005 to January 2006. Of the four species of mollusks analysed, we could not detect the presence of $C$. limnaei in Pomacea lineata (Spix, 1827). There were recorded 320 specimens of $C$. limnaei in association with Aplexa rivalis Mastou \& Rackett, 1898, Lymnaea columella Say, 1818 and Biomphalaria sp., the latter having the highest number of associated Naididae.
\end{abstract}

Keywords: abundance, freshwater gastropods, Naididae, prevalence.

\section{Ocorrência de Chaetogaster limnaei K. von Baer, 1927 (Oligochaeta, Naididae) associado com moluscos Gastropoda em canais de horticultura no sudeste do Brasil}

\begin{abstract}
Resumo
O objetivo deste estudo foi avaliar a presença de Chaetogaster limnaei K. von Baer, 1927 em quatro espécies de moluscos coletadas em canais de irrigação de uma horticultura no município de Juiz de Fora, Minas Gerais, sudeste do Brasil. As coletas foram realizadas de junho de 2005 a janeiro de 2006. Dentre as quatro espécies de moluscos analisadas, apenas em Pomacea lineata (Spix, 1827) não foi detectada a presença de C. limnaei. Foram registrados 320 espécimes de C. limnaei associadas a Aplexa rivalis Mastou \& Rackett, 1898, Lymnaea columella Say, 1818 e Biomphalaria sp., sendo esta última a espécie de molusco com o maior número de Naididae associados.
\end{abstract}

Palavras-chave: abundância, moluscos aquáticos, Naididae, prevalência.

\section{Introduction}

The studies of Kahl and Konopacka (1981), Righi (1984), Corbi et al. (2004, 2005) and Gorni and Alves (2006) refer to the association of Chaetogaster species with aquatic invertebrates. The association between Chaetogaster limnaei K. von Baer, 1927 and various species of gastropod mollusks has been reported many times (Gruffydd, 1965a; Andrade and Campos, 1968; Buse, 1972, 1974; Conn et al., 1995; Agbolade et al., 2007; Ibrahim, 2007; Fried et al., 2008), however the nature of this relationship has not yet been clearly defined (Callisto et al., 2005).

In the past, naturalists considered $C$. limnaei a true parasite, since they believed the species fed from the mucus produced by the host (Michelson, 1964). However, latter investigations showed that this species mainly feeds off diatoms, algae, protozoans and rotifers, thus being considered commensal (Grufyydd, 1965b; Semenas and Brugni, 1996).
There are few records of the presence of $C$. limnaei associated with aquatic mollusks in Brazil (Ruiz, 1951; Andrade and Campos, 1968; Callisto et al., 2005). Thus, the present work aimed to evaluate the presence of this Naididae in association with four species of mollusks collected in irrigation channels of a horticultural garden in the city of Juiz de Fora, Minas Gerais.

\section{Material and Methods}

The mollusks were collected along irrigation channels of a horticultural garden situated in the northwest region of the city of Juiz de Fora, Minas Gerais state ( $21^{\circ} 39^{\prime} 6^{\prime \prime} \mathrm{S}$ and $43^{\circ} 25^{\prime}$ '54" W) between June 2005 and January 2006. In total, 291 mollusks were collected using small nets; from these 75 were Aplexa rivalis Mastou \& Rackett, 1898, 75 Biomphalaria sp., 75 Lymnaea columella Say, 1827 and 69 Pomacea lineata (Spix, 1827). 
After shells were measured (diameter in B. straminea and height and width in the other species), gastropods were dissected under a stereoscopic microscope, in order to collect species of $C$. limnaei, which were put in formaldehyde $8 \%$ and kept in alcohol $70{ }^{\circ} \mathrm{GL}$. Taxonomic criteria adopted by Righi (1984) and Brinkhurst and Marchese (1991) were used for species identification.

The absolute abundance, mean abundance and prevalence of $C$. limnaei in each species of mollusk were determined. Due to the low prevalence of this Naididae in L. columella and $A$. rivalis, the mean density was determined only in Biomphalaria sp.. Moreover, the correlation degree between the area of the shell of Biomphalaria sp. and the prevalence of $C$. limnaei was evaluated. The Chaetogaster specimens were deposited at the Laboratory of Benthic Invertebrates at the Universidade Federal de Juiz de Fora (LIB-UFJF).

\section{Results and Discussion}

In the 291 mollusks analysed, 320 specimens of $C$. limane $i$ were recorded. Of the four species of mollusks analysed, the presence of $C$. limnae $i$ was not detected only in P. lineata. Biomphalaria sp., with 316 worms, was the species of mollusk with the highest number of associated specimens (Table 1).

C. limnaei showed higher prevalence in Biomphalaria sp. (56\%), and a lower one in A. rivalis and L. columella, both with $2.7 \%$. This result may reflect a true difference in host specificity, such as that shown by Buse (1974) for species of British gastropods.

The highest mean density (18.37 specimens $\left./ \mathrm{cm}^{2}\right)$ of C. limnaei in Biomphalaria sp. was observed in August 2005. In this month, the density varied between 1.85 ind. $\mathrm{cm}^{-2}$

Table 1. Total abundance, mean abundance and standard error of $C$. limnaei in three species of mollusks collected in irrigation channels of a horticultural garden (Juiz de Fora - MG) between June 2005 and January 2006.

\begin{tabular}{lcccccccc}
\hline & \multicolumn{2}{c}{ Biomphalaria sp. } & & \multicolumn{2}{c}{ Lymnaea columella } & & \multicolumn{2}{c}{ Aplexa rivalis } \\
\cline { 2 - 3 } & $\begin{array}{c}\text { Total } \\
\text { abundance }\end{array}$ & $\begin{array}{c}\text { Mean } \\
\text { abundance }\end{array}$ & & $\begin{array}{c}\text { Total } \\
\text { abundance }\end{array}$ & $\begin{array}{c}\text { Mean } \\
\text { abundance }\end{array}$ & & $\begin{array}{c}\text { Total } \\
\text { abundance }\end{array}$ & $\begin{array}{c}\text { Mean } \\
\text { abundance }\end{array}$ \\
\hline June-2005 & 12 & $0.80 \pm 0.30$ & - & - & - & - \\
July-2005 & 84 & $5.60 \pm 0.56$ & - & - & 2 & $0.13 \pm 0.06$ \\
August-2005 & 127 & $8.47 \pm 1.02$ & & 1 & $0.07 \pm 0.03$ & - & - & - \\
November-2005 & - & - & - & 1 & $0.07 \pm 0.03$ & & - & - \\
January-2006 & 93 & $6.20 \pm 0.45$ & & 1 & - & 2 & - \\
Total & 316 & - & & 2 & & - & - \\
\hline
\end{tabular}

Table 2. Association of Chaetogaster limnaei per area classes $\left(\mathrm{cm}^{2}\right)$ of Biomphalaria sp.

\begin{tabular}{|c|c|c|c|c|c|c|c|c|c|c|c|c|c|}
\hline \multirow{3}{*}{$\begin{array}{l}\text { Area } \\
\left(\mathrm{cm}^{2}\right)\end{array}$} & \multicolumn{13}{|c|}{ Biomphalaria sp. } \\
\hline & \multicolumn{2}{|c|}{$\begin{array}{l}\text { Collected } \\
\text { and } \\
\text { examined }\end{array}$} & \multicolumn{9}{|c|}{$\begin{array}{c}\text { Totals of mollusk according } \\
\text { to the number of associated } \\
\text { Chaetogaster limnaei }\end{array}$} & \multicolumn{2}{|c|}{$\begin{array}{c}\text { Number of } \\
\text { mollusks with } \\
\text { Chaetogasterlimnaei } \\
\text { associated }\end{array}$} \\
\hline & $\mathbf{N}^{\mathbf{o}}$ & $\%$ & $\mathbf{0}$ & 1-3 & 4-6 & 7-9 & 10-12 & 13-15 & 16-18 & 19-22 & 23-27 & $\mathbf{N}^{\mathbf{o}}$ & $\%$ \\
\hline $0.30-0.39$ & 1 & 1.33 & 1 & - & - & - & - & - & - & - & - & 0 & - \\
\hline $0.40-0.49$ & 1 & 1.33 & 1 & - & - & - & - & - & - & - & - & 0 & - \\
\hline $0.50-0.59$ & 9 & 12.00 & 8 & - & - & - & - & - & - & - & 1 & 1 & 1.33 \\
\hline $0.60-0.69$ & 20 & 26.66 & 10 & 4 & 2 & 1 & 1 & - & 1 & 1 & - & 10 & 13.33 \\
\hline $0.70-0.79$ & 6 & 8.00 & 2 & - & - & 3 & - & - & 1 & - & - & 4 & 5.33 \\
\hline $0.80-0.89$ & 14 & 18.66 & 5 & 4 & 1 & 1 & 2 & 1 & - & - & - & 9 & 12.00 \\
\hline $0.90-0.99$ & 3 & 4.00 & 1 & 1 & 1 & - & - & - & - & - & - & 2 & 2.67 \\
\hline $1.00-1.09$ & 6 & 8.00 & 2 & 3 & - & - & - & - & - & 1 & - & 4 & 5.33 \\
\hline $1.10-1.19$ & 1 & 1.33 & - & - & - & - & 1 & - & - & - & - & 1 & 1.33 \\
\hline $1.20-1.29$ & 4 & 5.33 & 1 & 1 & - & 2 & - & - & - & - & - & 3 & 4.00 \\
\hline $1.30-1.39$ & 4 & 5.33 & 1 & - & 1 & 1 & 1 & - & - & - & - & 3 & 4.00 \\
\hline $1.40-1.49$ & 4 & 5.33 & 1 & 1 & - & 1 & 1 & - & - & - & - & 3 & 4.00 \\
\hline $1.50-1.59$ & 1 & 1.33 & - & - & - & 1 & - & - & - & - & - & 1 & 1.33 \\
\hline : & - & - & - & - & - & - & - & - & - & - & - & 0 & - \\
\hline $1.90 \rightarrow 1.99$ & 1 & 1.33 & - & - & 1 & - & - & - & - & - & - & 1 & 1.33 \\
\hline Total $n^{\circ}$ & 75 & - & 33 & 14 & 6 & 10 & 6 & 1 & 2 & 2 & 1 & 42 & 56.00 \\
\hline$(\%)$ & - & 100.00 & 44.00 & 18.67 & 8.00 & 13.33 & 8.00 & 1.33 & 2.67 & 2.67 & 1.33 & - & - \\
\hline
\end{tabular}


and 52.08 ind.cm ${ }^{-2}$. However, in November 2005, no worm was found.

It was observed that $C$. limnae $i$ was present in a higher number in Biomphalaria sp. with its shell area ranging from 0.60 to $0.69 \mathrm{~cm}(\mathrm{n}=10)$ and from 0.80 to $0.89 \mathrm{~cm}(\mathrm{n}=9)$ making a total of $25.3 \%$ of the mollusks associated with C. limnaei. This indicates that there was no correlation between host size and the presence of this Naididae (P $>0.05)$. A similar result was obtained by Conn et al. (1995) with the bivalves Dreissena polymorpha Pallas, 1771 and Dreissena bugensis Andrusov, 1897. However, Andrade and Campos (1968) detected a positive relation between the size of $B$. straminea and the prevalence of C. limanei.

The number of $C$. limnaei present in Biomphalaria sp. ranged from 1 to 27 specimens, and a higher number of mollusks with 1 to 3 organisms (Table 2) was observed. The maximum number of $C$. limnaei found was close to that found by Andrade and Campos (1968), in which the maximum number was 23 worms per B. Straminea; however, it is quite inferior to 70 parasites/host found by Gruffydd (1965b).

In conclusion, these results attest the ability of Chaetogaster limnaei to use different organisms that are present in an aquatic environment as substrate, and also they show the preference of this Naididae for Gastropods of the genus Biomphalaria.

Acknowledgements - We are grateful to Roberto Junio Pedroso Dias for the fruitful suggestions. We would like to thank Prof. Gilson Alexandre de Castro for identifying the snails, the biologist Luciana Falci Theza Rodrigues for helping with the material collection and identification. Finally we thank PPGCBA-UFJF.

\section{References}

AGBOLADE, OM., GLEDHIL, T., FAJEBE, OT., ABOLADE, OM. and OLATEJU, TM., 2007. Population, seasonal abundance, Dockovdia oruensis infection and other parasites of Potadoma moerchi in southwestern Nigeria. African Journal of Biotechnology, vol. 6 , no. 6, p. 826-830.

ANDRADE, RM. and CAMPOS, LG., 1968. Natural infection of Biomphalaria straminea (Dunker, 1848) by oligochaetes of the genus Chaetogaster. Revista Brasileira de Malariologia e Doenças Tropicais, vol. 21, no. 1, p. 27-36.

BRINKHURST, RO. and MARCHESE, MR., 1991. Guia para la identificación de oligoquetos aquáticos continentales de sur y Centroamérica. Argentina: Associación de Ciências Naturales del Litoral. 207 p.

BUSE, A., 1972. Behavioural aspects of the relatonship of Chaetogaster limnaei (Oligochaeta: Naididae) with its gastropod host. Animal Behaviour, vol. 20, no. 2, p. 274-279.

BUSE, A., 1974. The relationship of Chaetogaster limnaei (Oligochaeta: Naididae) with a variety of gastropod species. Journal of Animal Ecology, vol. 43, p. 821-837.
CALLISTO, M., MORENO, P., GONÇALVES JÚNIOR, JF., FERREIRA, WR. and GOMES, CLZ., 2005. Malacological assessment and natural infestation of Biomphalaria straminea (Dunker, 1848) by Schistosoma mansoni (Sambon,1907) and Chaetogaster limnaei (K. Von Baer,1827) in an urban eutrophic watershed. Brazilian Journal of Biology, vol. 65, no. 2, p. 1-13.

CONN, DB., RICCIARDI, A., BABAPULLE, MN., KLEIN, KA. and ROSEN, DA., 1995. Chaetogaster limnaei (Annelida: Oligochaeta) as a parasite of the zebra mussel Dreissena polymorpha, and the quagga mussel Dreissena bugensis (Mollusca: Bivalvia). Parasitology Research, vol. 82, no. 1, p. 1-7.

CORBI, JJ., JANCOSO, MA., TRIVINHO-STRIXINO, S. and FRAGOSO, EN., 2004. Occurence of oligochaeta living on larvae of odonata from Ipeúna (São Paulo State, Brazil). Biota Neotropica, vol. 4, no. 2. Available from: <http://www.biotaneotropica.org. br/v4n2/pt/abstract?short-communication+BN03304022004>. Access in: 10/06/2008.

CORBI, JJ., ROQUE, FO., TRIVINHO-STRIXINO, S. and ALVES, RG., 2005. Records of oligochaetes in freshwater sponges, on bryozoans, and on colonial hydrozoans from Brazil. Brazilian Journal of Biology, vol. 65, no. 1, p. 187-188.

FRIED, B., PEOPLES, RC., SAXTON, TM. and HUFFMAN, JE., 2008. The Association of Zygocotyle lunata and Echinostoma trivolvis with Chaetogaster limnaei, an Ectosymbiont of Helisoma trivolvis. Journal of Parasitology, vol. 94, no. 2, p. 553-554.

GORNI, GR. and ALVES, RG., 2006. Naididae (Annelida, Oligochaeta) associated with Pomacea bridgesii (Reeve) (Gastropoda, Ampullaridae). Revista Brasileira de Zoologia, vol. 23, no. 4, p. $1059-1061$.

GRUFFYDD, LD., 1965a. The population biology of Chaetogaster limnaei limnaei and Chaetogaster limnaei vaghini (Oligochaeta). Journal of Animal Ecology, vol. 34, p. 667-90.

GRUFFYDD, LD., 1965b. Evidence for the existence of a new subspecies of Chaetogaster (Oligochaeta), in Britain. Journal of Zoology, vol. 146, p. 175-196.

IBRAHIM, MM., 2007. Population dynamics of Chaetogaster limnaei (Oligochaeta: Naididae) in the field populations of freshwater snails and its implications as a potential regulator of trematode larvae community. Parasitology Resource, vol. 101, no. 1 , p. $25-33$

KAHL, K. and KONOPACKA, A., 1981. Oligochaeta inhabiting the colonies of the sponge Spongilla lacustris (L.) in the river Gaé. Acta Hydrobiologica, vol. 23, no. 3, p. 243-249.

MICHELSON, EH., 1964. The protective action of Chaetogaster limnaei on snails exposed to Schistosoma mansoni. The Journal of Parasitology, vol. 50, no. 3, p. 441-444.

RIGHI, G., 1984. Oligochaeta. In SCHADEN, R. (Ed.). Manual de identificação de invertebrados límnicos do Brasil. Brasília: CNPq. 48 p.

RUIZ, JM., 1951. Nota sobre a cercariofagia de um Oligochaeta do gênero Chaetogaster, v. Baer, 1827. Anais da Faculdade de Farmácia e Odontologia da Universidade de São Paulo, vol. 9, p. 51-56.

SEMENAS, L. and BRUGNI, N., 1996. Presencia de Chaetogaster limnaei (Oligochaeta: Naididae) em moluscos de lagos andinospatagónicos. Neotropica, vol. 42, no. 107-108, p. 119-120. 
